\title{
Az autoantitestek jelenlétének és a maradék inzulintermelésnek a hatása az anyagcserekontroll minőségére diabeteses gyermekekben
}

\author{
Körner Anna dr.
}

\begin{abstract}
Osszefoglalás
1-es típusú diabetesben a pancreas béta-sejtjeinek immunmediált pusztulása már hosszú idövel a betegség kórismézése elött elkezdődik, és még évekkel a diagnózis felállitását követöen is folytatódik. Mindezek alapján a szerzö megvizsgálta, hogy az autoimmun folyamat pancreas-autoantitesttiterrel jellemzett aktivitása milyen hatással van a maradék inzulintermelés mértékére és az anyagcserekontroll minöségére 1-es típusú diabetesben szenvedö gyermekekben. A vizsgálat során a szerzö gondozottai közül 171 véletlenszerüen kiválasztott gyermek adatait elemezte. Az eredmények alapján a manifesztációs életkor meghatározta mind a diagnózis idején mért C-peptid-szintet, mind az induló HbA ${ }_{1 c}$-értéket, de a várakozással ellentétben nem volt hatással sem a diagnóziskor észlelt hyperglykaemia mértékére, sem a sav-bázis eltérésekre. Ez a tendencia a késöbbiekben is megmaradt; a betegek életkora a vizsgálat idején is jelentös hatással volt az aktuális C-peptid-szintre és a $\mathrm{HbA}_{1}$-re is. Az autoantitest (glutaminsavdekarboxiláz) indulótitere független volt a manifesztációs életkortól, de szoros összefüggést mutatott az évekkel késöbb, a vizsgálat idején mért antitesttiterrel. A várakozásnak megfelelöen a C-peptid-szinttel jellemzett maradék inzulintermelés mértéke a diabetestartam növekedésével párhuzamosan jelentösen csökkent.
\end{abstract}

Kulcsszavak: 1-es tipusú diabetes, gyermek, autoantitestek, C-peptid, HbA 1 c

\section{Effect of auto-antibodies and insulin secretory reseve capacity on metabolic control in children with diabetes}

Summary: Immun-mediated destruction of the pancreatic beta cells starts already years before the diagnosis of type 1 diabetes, and the process is going on for years after manifestation. On the basis of this consideration the effect of autoimmune process activity, characterized by pancreas auto-antibodies on insulin secretory reserve capacity as well as on the quality of metabolic control in children with type 1 diabetes has been studied. Data of randomly selected 171 children have been analyzed. According to the results age at manifestation had an impact both on C-peptide level at diagnosis and on initial $\mathrm{HbA}_{1 c}$ value, but surprisingly not on measure of hyperglycemia and acid base status at diagnosis. This tendency was well reserved even later on; age at data analysis has influenced both actual C-peptide level and HbA ${ }_{1 c}$. Initial auto antibody (glutamic acid decarboxilase) titer was independent of age at manifestation, but was strongly related to the antibody titer observed years later at the time of the investigation. According to expectations insulin secretory reserve capacity characterized by C-peptide level has significantly decreased parallel to the increase in diabetes duration.

Key words: type 1 diabetes, child, auto-antibodies, C-peptide, HbA

Röviditések

DCCT: Diabetes Control and Complications Trial; $\mathbf{H b A}_{1 \mathbf{c}}$ : glikált Hb; GAD: glutaminsavdekarboxiláz; MDI: konzervatív intenziv inzulinkezelés (multiple daily [insulin] injection) 
1 -es típusú diabetesben a hasnyálmirigy béta-sejtjei autoimmun folyamat következtében fokozatosan elpusztulnak. A betegséget az autoantitestek megjelenése jelzi, és a folyamat előbb vagy utóbb az inzulintermelés teljes megszűnéséhez vezet. ${ }^{1}$ A SEARCH for Diabetes in Youth study tanúsága szerint az autoantitest-pozitív betegek körében függetlenül a demográfiai jellemzőktől, az autoimunitás iránti genetikai hajlamtól, a $\mathrm{HbA}_{1 \mathrm{c}}$-től és a testtömegindex-zscore-tól, a béta-sejt-funkció progresszív csökkenése mutatható ki. A vizsgálat az éhezési C-peptid-szinttel jellemzett béta-sejt-funkció legfőbb meghatározóira irányult. ${ }^{2}$ Eredményei alapján a diabetes diagnózisát követően is a legfőbb szerepet a béta-sejt-pusztulásban az autoimmunitás játssza. Az irodalomban a béta-sejt-tömeg vesztésének üteme az egyes vizsgálatok között változó, amit részben a vizsgált populáció heterogenitása, részben az eltérő vizsgálati módszer (éhezési vagy stimulált $C$-peptid-szint) magyaráz. A diagnózist követő első évben egyes szerzők a béta-sejt-funkció csak mérsékelt csökkenését észlelték, ${ }^{3,4}$ míg mások - hasonlóan a SEARCH for Diabetes in Youth study eredményeihez - a béta-sejt-tömeg mintegy 50\%-ának elvesztéséről számoltak be., ${ }^{5,6,7}$

Vizsgálatunk célja annak megállapítása volt, milyen összefüggések fedezhetők fel a pancreas-autoantitestek jelenléte, az inzulinrezerv kapacitás és az anyagcserekontroll minősége között.

\section{1. táblázat. A betegek demográfiai jellemzői}

\begin{tabular}{|c|c|}
\hline A vizsgált gyermekek száma & 171 \\
\hline Fiú/leány & $91 / 80$ \\
\hline A kezelés típusa (MDI+premix/CSII) & $105 / 66$ \\
\hline Manifesztációs életkor (év) & $6,7 \pm 3,9$ \\
\hline Életkor a vizsgálat idején (év) & $12,3 \pm 3,6$ \\
\hline Betegségtartam (év) & $5,7 \pm 2,9$ \\
\hline Vércukor a manifesztáció idején (mmol/l) & $26,4 \pm 11,6$ \\
\hline pH a manifesztáció idején & $7,31 \pm 0,13$ \\
\hline HbA $A_{1 c}$ a manifesztáció idején (\%) & $10,9 \pm 2,3$ \\
\hline C-peptid-szint a manifesztáció idején $(\mathrm{ng} / \mathrm{ml})$ & $0,55 \pm 0,45$ \\
\hline GAD-titer a manifesztáció idején (U/ml) & $305 \pm 555$ \\
\hline
\end{tabular}

MDI: multiple daily injection, konzervatív intenzív inzulinkezelés; CSII: continuous subcutaneous insulin infusion, inzulinpumpa kezelés; GAD: Glutaminsavdekarboxiláz

\section{Betegek és módszerek}

A vizsgálatba az általam gondozott diabeteses gyerekek közül 171 véletlenszerűen kiválasztott beteget vontam be. Demográfiai adataikat az 1. táblázat mutatja. A táblázatból leolvasható, hogy a vizsgálatban valamivel több fiú, mint lány vett részt. Kevesebb mint egyharmadukat inzulinpumpával, többségüket konzervatív intenzív inzulinterápiával (multiple daily [insulin] injection - MDI) kezeltük. Kis hányaduk (a legfiatalabbak) premix kezelésben részesült. A manifesztációkor többségük 10 éves kor alatt volt, a vizsgálat idején legtöbbjük már pubertáskorba lépett. Bár a követési idő betegenként különböző volt, átlagos betegségtartamuk ekkor már meghaladta az 5 évet. A manifesztációkor észlelt vércukor, vér-pH, $\mathrm{HbA}_{1 \mathrm{c}}$ és az endogén inzulinrezerv kapacitást tükröző C-peptid-szint a gyermekkorban fellépő 1-es típusú diabetesre jellemző értékeket mutatta. A pancreas-autoantitestek közül meghatározott glutaminsavdekarboxiláz (GAD) átlagos titer a normális értéket $(<5 \mathrm{U} / \mathrm{ml})$ jelentősen meghaladta.

$\mathrm{Az}$ újonnan diagnosztizált betegekben a manifesztációkor észlelt vércukor-, vér-pH-, $\mathrm{HbA}_{1 \mathrm{c}}$ - és a C-peptid-szint vizsgálatára a vérvétel a klinikára érkezés idején, a kezelés megkezdése előtt történt. Bizonyos, a kezelés által rövid távon nem befolyásolható paraméterek (GAD-titer) meghatározása esetenként némi késéssel, de mindenképpen az első 48 órában zajlott. A későbbiekben a vérvételek az éves ellenőrző vizsgálatok keretében, éhgyomorra történtek.

A standard laboratóriumi módszerek alkalmazása mellett a glikált Hb szintjét folyadékkromatográfiával, a C-peptid-értéket kemolumineszcenciás módszerrel, a glutaminsavdekarboxiláz titerét ELISA módszerrel, illetve immunfluoreszcenciával határoztuk meg.

A statisztikai analízishez átlag- és szórásszámítást, egy- és kétmintás t-próbát, valamint korrelációanalízist végeztem. A p $<0,05$-ös értéket tekintettem statisztikailag szignifikánsnak.

\section{Eredmények}

Szignifikáns pozitív összefüggést állapítottunk meg a manifesztációs életkor és a C-peptid-szinttel jellemzett maradék inzulintermelés között; minél idősebb volt a gyerek a diabetes manifesztációjakor, annál nagyobb endogén inzulinrezervvel rendelkezett (1. ábra). Ennek ellenére az idősebb gyermekek glikált $\mathrm{Hb}$ szintje a manifesztációkor kismértékben, de szignifikánsan magasabb volt ( 2 . ábra). A manifesztációs életkor nem mutatott öszszefüggést sem az aktuális vércukorszinttel, sem az 


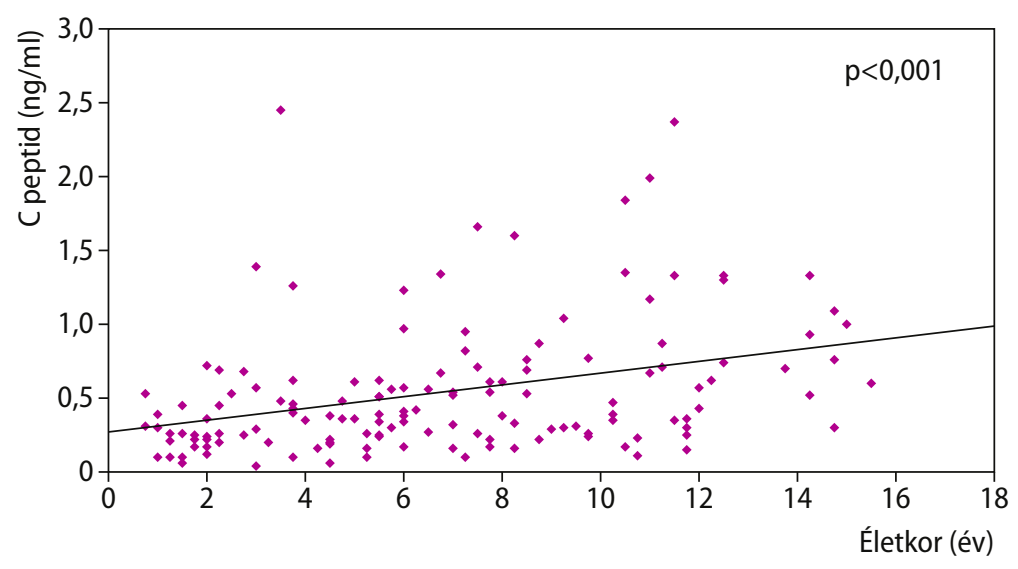

1. ábra. A maradék inzulintermelés és az életkor összefüggése a diabetes manifesztációjakor

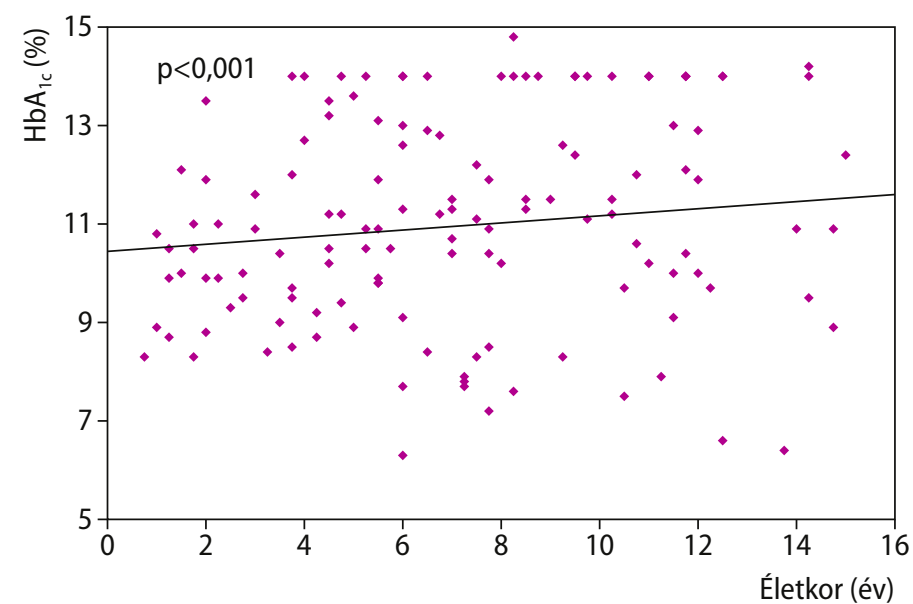

2. ábra. A manifesztációkor észlelt $H b A_{1 c}$ és az életkor összefüggése

aktuális pH-értékkel, sem a manifesztációs GADtiterrel. Megjegyzendő azonban, hogy az extrémen magas (>1000 U/ml-es) GAD-titer a kisebb gyerekek között gyakoribb volt, ami a fiatalabb gyerekek agresszívebb autoimmun folyamatára utal. A várakozásnak megfelelően a betegségtartam előrehaladtával az endogén inzulinrezerv csökken (3. ábra), és ezzel párhuzamosan a $\mathrm{HbA}_{1 \mathrm{c}}$ emelkedik (4. ábra). Az idősebb gyerekek $\mathrm{HbA}_{1 \mathrm{c}}$-je az utánkövetésnél is magasabbnak mutatkozott (5. ábra), miközben az idősebb gyermekekben a betegség előrehaladtával is több endogén inzulintermelés marad (6. ábra). Mindezek alapján úgy tűnik, hogy a pubertásban jelentkező rossz adherenciával a viszonylagosan nagyobb endogén inzulinrezerv sem képes megbirkózni. Vizsgálataink szerint, akinek induláskor magasabb volt az antitesttitere, annak később is az maradt $(\mathrm{p}<0,05)$. Érdekes és további vizsgálatokat igénylő megfigyelés, hogy néhány gyereknek az utánkövetéskor magasabb 


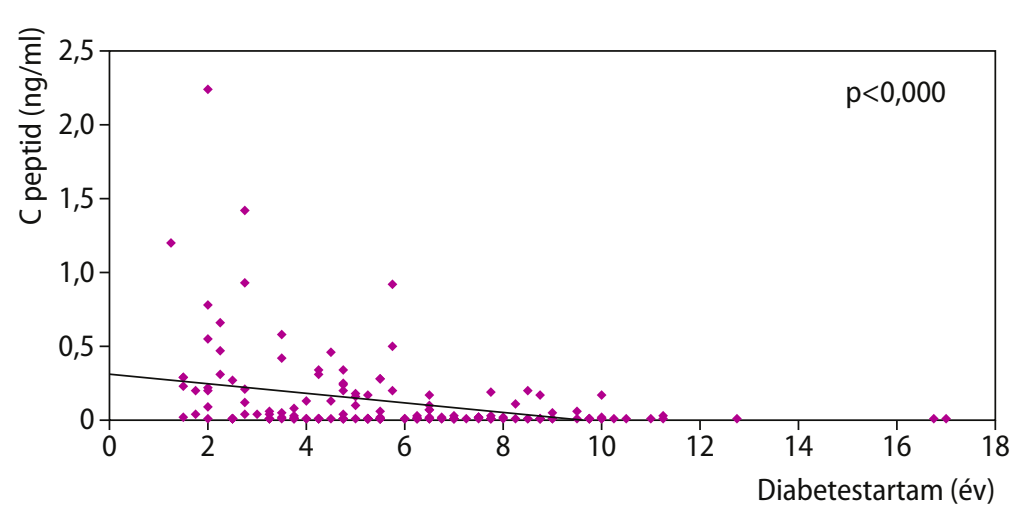

3. ábra. A betegségtartam és az endogén inzulinrezerv kapacitás összefüggése

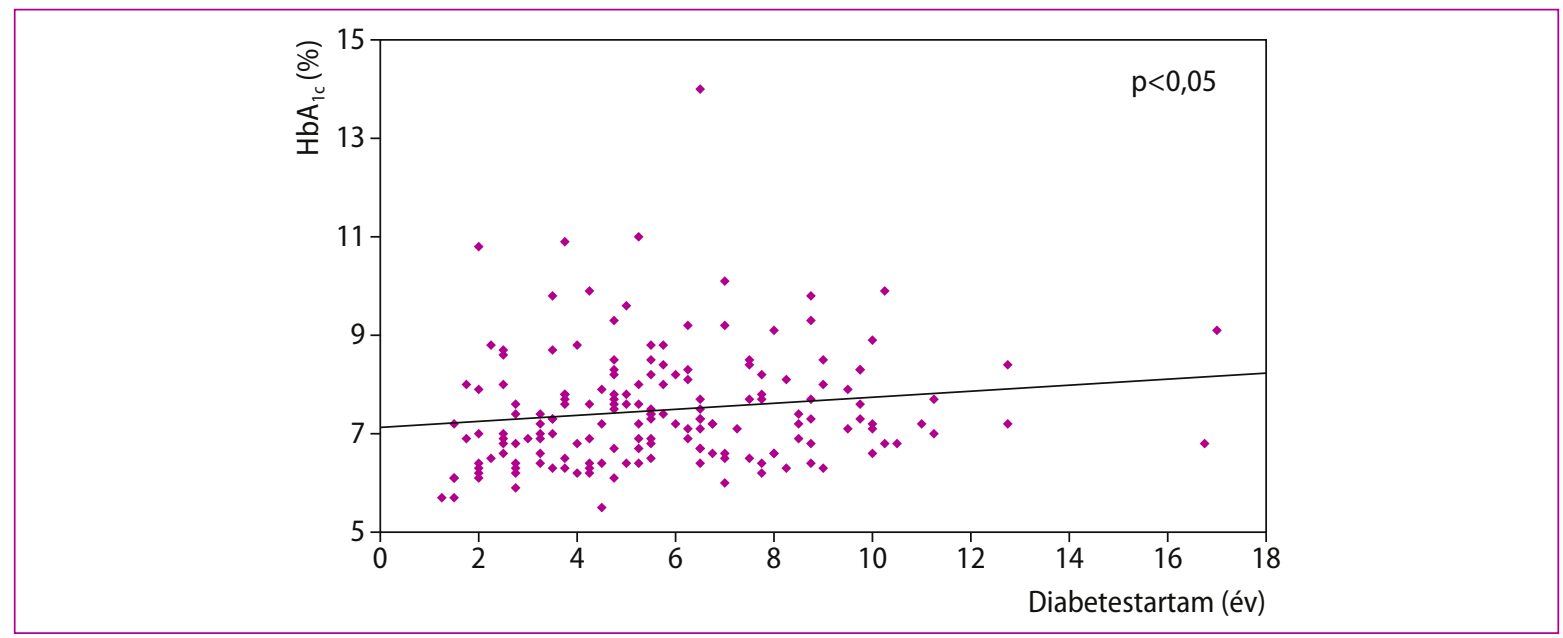

4. ábra. A HbA ${ }_{1 c}$-szint összefüggése a betegségtartammal

volt a GAD-titere, mint a manifesztációkor, valamint hogy néhányukban akkor is emelkedett volt a GAD-titer, amikor endogén inzulinrezerv kapacitás már nem volt kimutatható. Végezetül összehasonlítottuk betegeinket a kezelési mód alapján. $\mathrm{Az} \mathrm{MDI} /$ premix rezsimmel kezelt, illetve inzulinpumpa-terápiában részesülő diabeteses gyermekek jellemzőinek összehasonlítását a 2. táblázat mutatja. A táblázatból látható, hogy az MDI/premix csoport életkora mind a manifesztációkor, mind a vizsgálat idején magasabb volt, mint az inzulinpumpával kezelt csoporté. Ez jól tükrözi azt a terápiás szemléletet, hogy elsősorban a fiatalabb gyermekeket kezeljük inzulinpumpával. Ez utóbbi csoport diabetestartama a vizsgálat idején hoszszabb volt, mint a konzervatív rezsimmel kezelt gyermekeké. Míg az MDI/premix csoport idősebb gyermekeinek indulási $\mathrm{HbA}_{1 \mathrm{c}}$-szintje magasabb volt, nem volt különbség sem a manifesztációs vércukorszintben, sem a $\mathrm{pH}$-értékben, illetve $\mathrm{C}$ peptid-szintben és GAD-titerben sem. A vizsgálat idején a két csoport $\mathrm{HbA}_{1 \mathrm{c}}$-szintje és GAD-titere statisztikailag nem különbözött egymástól, ugyanakkor a C-peptid-szint az inzulinpumpás csoportban szignifikánsan alacsonyabb volt. Ennek az első pillanatban meghökkentő eredménynek a hátteré- 


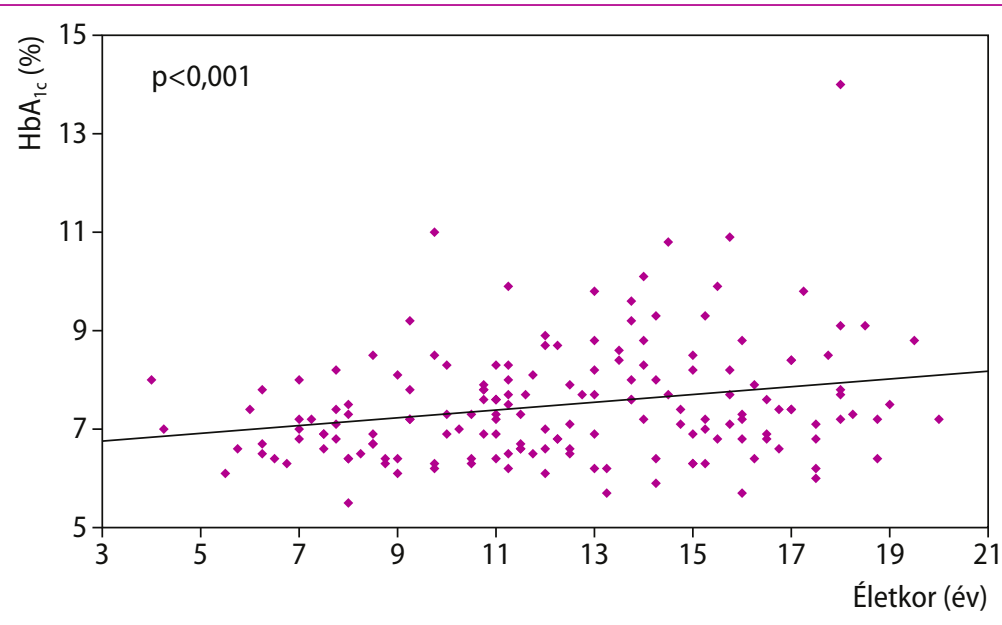

5. ábra. $A H b A_{1 c}$ összefüggése az életkorral a vizsgálat idején

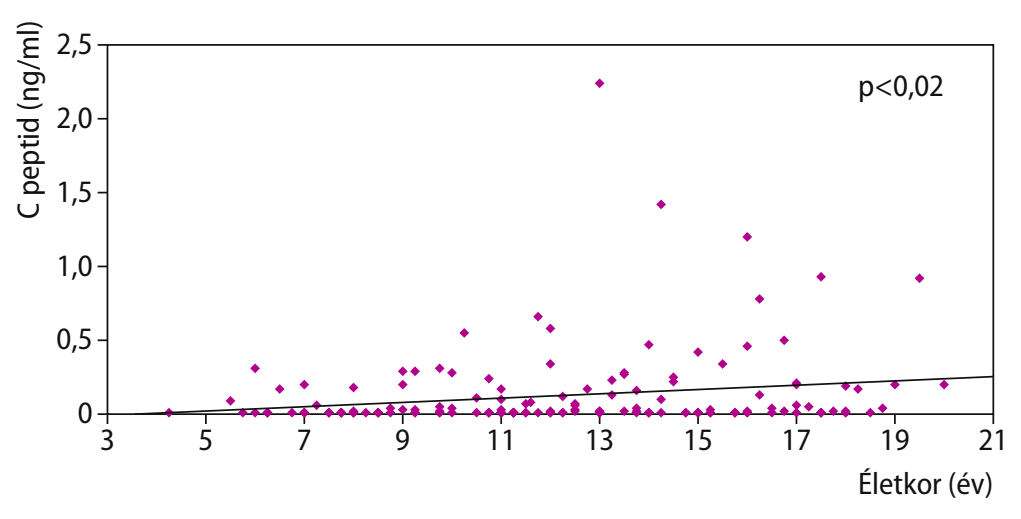

6. ábra. Az endogén inzulintermelést jellemző C-peptid-szintek kapcsolata a vizsgálatkor észlelt életkorral

\section{2. táblázat. A betegek összehasonlítása a kezelési mód alapján}

\begin{tabular}{|c|c|c|c|}
\hline & MDI/Premix & Inzulinpumpa-kezelés & Szignifikancia \\
\hline Manifesztációs életkor (év) & $8,0 \pm 3,7$ & $4,5 \pm 3,1$ & $p<0,001$ \\
\hline Életkor a vizsgálat idején (év) & $12,8 \pm 3,7$ & $11,6 \pm 3,5$ & $p<0,02$ \\
\hline Diabetestartam (év) & $4,9 \pm 2,3$ & $7,0 \pm 3,2$ & $p<0,000$ \\
\hline Vércukorszint a a manifesztációkor ( $\mathrm{mmol} / \mathrm{l})$ & $25,8 \pm 11,5$ & $27,4 \pm 11,8$ & NS \\
\hline pH a manifesztációkor & $7,3 \pm 0,1$ & $7,3 \pm 0,1$ & NS \\
\hline $\mathrm{HbA}_{1 \mathrm{c}}$ a manifesztációkor (\%) & $11,2 \pm 2,4$ & $10,5 \pm 2,0$ & $\mathrm{p}<0,04$ \\
\hline GAD-titer a manifesztációkor (U/ml) & $276 \pm 541$ & $396 \pm 620$ & NS \\
\hline C-peptid-szint a manifesztációkor (ng/ml) & $0,55 \pm 0,4$ & $0,53 \pm 0,5$ & NS \\
\hline $\mathrm{HbA}_{1 c}$-szint a vizsgálat idején (\%) & $7,5 \pm 1,3$ & $7,4 \pm 0,9$ & NS \\
\hline GAD-titer a vizsgálat idején (U/ml) & $263 \pm 559$ & $180 \pm 462$ & NS \\
\hline C-peptid-szint a vizsgálat idején ( $\mathrm{ng} / \mathrm{ml})$ & $0,19 \pm 0,33$ & $0,03 \pm 0,06$ & $p<0,000$ \\
\hline
\end{tabular}


ben egy egyszerű tény állt. Minthogy a vérvételek éhgyomorra történtek, a reggeli inzulin beadásának későbbi időpontra kerülése a hagyományos módon kezelt betegcsoportban jelentős vércukor-emelkedéshez vezetett, az inzulinpumpások esetében azonban a bázisinzulin-adagolás megakadályozta a vércukor-emelkedést $(12,7 \pm 2,6$ vs. $6,1 \pm 1,7 \mathrm{mmol} / \mathrm{l}, \mathrm{p}<0,01)$.

\section{Megbeszélés}

Vizsgálataink alapján minél idősebb a gyerek a diabetes manifesztációjakor, annál nagyobb endogén inzulinrezervvel rendelkezik. Ez a megállapítás jól harmonizál más szerzők eredményeivel, akik szintén azt találták, hogy fiatalabb gyermekekben a diagnóziskor észlelt C-peptid-szint az idősebbekkel összehasonlítva alacsonyabb. ${ }^{8,9,10} \mathrm{Ez}$ egyrészt azzal magyarázható, hogy a kisebb gyermekek béta-sejttömege eleve alacsonyabb, másrészt azt is sugallja, hogy a fiatalabbakban az autoimmun folyamat agresszívabb. Ez utóbbi megállapítást látszik alátámasztani az a megállapításunk, hogy az extrémen magas (>1000 U/ml-es) GAD-titer a kisebb gyerekek között gyakoribb volt. Eredményeink jól összecsengenek Bizzarri és munkatársainak megállapításával, akik 290 diabeteses gyermek adatainak elemzése során szintén azt találták, hogy fiatalabb gyermekekben - az intenzívebb autoimmun támadás következtében - alacsonyabb a C-peptidszint és magasabb az autoantigéntiter, mint az idősebbekben. ${ }^{11}$ Megjegyzendő az is, hogy az általunk vizsgált egyetlen pancreas autoantigén vizsgálata nem teszi lehetővé messzemenő következtetések levonását az autoantitestek és az endogén rezerv kapacitás összefüggésének elemzésére. Egy multicentrikus vizsgálat közel 4000 diabeteses beteg adatainak feldolgozása során szintén pozitív öszszefüggést talált az életkor és az éhezési C-peptidszint között. ${ }^{12} \mathrm{Az}$ idősebb gyermekekben a diagnóziskor észlelt magasabb éhezési C-peptid-szint fényében kissé meglepő, hogy az idősebb gyermekek manifesztációs $\mathrm{HbA}_{1 c}$-szintje a nagyobb endogén inzulinrezerv kapacitás ellenére magasabb volt. Ugyanakkor Mazarello Paes és munkatársai a szakirodalmat áttekintve 20 vizsgálat adatainak összegzéséből szintén arra a megállapításra jutottak, hogy az idősebb gyerekek $\mathrm{HbA}_{1 \mathrm{c}}$-je 0 -3 hó- nappal a diagnózis felállítása után magasabb, mint a fiatalabb gyermekeké. ${ }^{13}$ Ennek legkézenfekvőbb magyarázata az a jelenség, hogy az idősebb gyermekek a diagnózist megelőző időszakban a megnövekedett étvágy következtében nagyobb hyperglykaemiás terhelésnek vannak kitéve, míg a kisebb gyermekekre a fokozott tápanyagbevitel kevésbé jellemző. Az irodalmi adatok jól alátámasztják megfigyelésünket, hogy a C-peptid-szinttel jellemzett endogén inzulinrezerv kapacitás a betegségtartam előrehaladásával csökken, és ezzel párhuzamosan a $\mathrm{HbA}_{1 c}$-szint emelkedik. ${ }^{12,14,15} \mathrm{Az}$ aktuális $\mathrm{HbA}_{1 \mathrm{c}}$ - és a C-peptid-szint között - életkortól és tartamtól függetlenül - inverz korreláció áll fenn. ${ }^{16}$ Ennek látszólag ellentmond az a megfigyelésünk, hogy idősebb gyermekekben a magasabb C-peptid-szint ellenére is magasabb a glikált $\mathrm{Hb}$ szintje. Ugyanakkor ismert, hogy $\mathrm{HbA}_{1 \mathrm{c}}$ diabeteses gyermekekben az életkor növekedésével fokozatosan emelkedik, és csak 18 éves kor felett kezd újra csökkenni. ${ }^{17}$ A legmarkánsabb az anyagcserekontroll minőségének romlása a pubertásban. Ennek a jelenségnek az okai összetettek; a testtömeg növekedése, a pubertásban fellépő inzulinrezisztencia és nem utolsósorban azok a pszichoszociális tényezők, amelyek ebben az életkorban a diabetes menedzselésében komoly kihívást jelentenek. ${ }^{18}$ A DCCT-ben (Diabetes Control and Complications Trial) is az adoleszcens csoport átlagos $\mathrm{HbA}_{1 c}$-je - a kezelési rezsimtől függetlenül $1 \%$-kal magasabb volt, mint a felnőtteké. ${ }^{19}$

A kezelési mód (MDI/premix rezsim, illetve inzulinpumpával kezelt betegek) alapján csoportosított betegek között a manifesztációs életkorban és a diabetestartamban jelentős, a vizsgálat idején észlelt életkorban kis, de szignifikáns különbség mutatkozott. A diagnózis idején idősebb $\mathrm{MDI} /$ premix csoportban az induló $\mathrm{HbA}_{1 \mathrm{c}}$ magasabb volt, ez azonban a vizsgálat idejére kiegyenlítődött, és ekkorra már mindkét betegcsoport jó anyagcserekontrollt ért el. Megjegyzendő, hogy vizsgálatunk nem alkalmas a hagyományos és inzulinpumpa-kezelés érdemi összehasonlítására az anyagcserekontroll minősége szempontjából, hiszen a pumpakezelés tartama a csoporton belül igen különböző volt. A legmeghökkentőbb különbség a két csoport között az éhezési C-peptidszintben mutatkozott, ami a hagyományos kezelésben részesülő betegekben szignifikánsan magasabb 
volt. A váratlan jelenség magyarázata - ahogyan azt az eredmények ismertetésénél már jeleztük - a vizsgálat idején mért vércukorszintben rejlik. $\mathrm{Az}$ éhomi vérvétel miatt a gyerekek a reggeli inzulinadagjukat a szokásosnál 1,5-2 órával később kapták meg. Ez az inzulinpumpával kezeltekben - ahol a bázisinzulin folyamatosan adagolódott nem okozott érdemi vércukorszint-emelkedést, a hagyományosan kezelt csoportban azonban szignifikánsabb magasabb éhomi vércukorszintet eredményezett. A C-peptid-szint és a vércukorszint között fennálló kapcsolat értelmében a magasabb vércukorszint magasabb C-peptid-szintet eredményezett. Mindez felhívja a figyelmet arra is, hogy az éhomi C-peptid-szint - szemben a stimulált Cpeptid-szinttel - nem feltétlenül tükrözi híven az endogén inzulinrezerv kapacitást. ${ }^{20,21}$ Jól támasztja ezt alá a DCCT vizsgálat is, amelyben az éhomi C-peptid-szint csupán gyenge, míg a stimulált C-peptid-szint szoros összefüggést mutatott a szövődményekkel. ${ }^{22}$

A klinikus, ha elég hosszú időt tölt el a betegek megfigyelésével, számos tapasztalatra tesz szert. Amikor azonban szubjektív megfigyeléseit objektív statisztikai módszerekkel szembesíti, néha saját maga számára is meglepő eredményekkel találja magát szemben. A 171, véletlenszerűen kiválasztott gyermek adatainak elemzése során jól megfelelt várakozásaimnak, hogy az idősebb gyermekekben a magasabb induló $\mathrm{HbA}_{1 c}$ ellenére nagyobb endogén inzulinrezerv kapacitást találtunk. Ugyanakkor - a kisgyermekek nagyobb esendősége miatt - meglepett, hogy nem találtam összefüggést a gyermekek manifesztációs életkora és a diagnóziskor észlelt hyperglykaemia mértéke, illetve a sav-bázis eltérések között. Bár egyetlen pancreasantitest (GAD) meghatározása csak korlátozott jellegű következtetéseket enged meg, érdekes volt látni, hogy az induló autoantitesttiter független volt a manifesztációs életkortól, ugyanakkor szoros összefüggést mutatott az évekkel később, a vizsgálat idején mért antitesttiterrel. A várakozásnak megfelelően a C-peptid-szinttel jellemzett maradék inzulintermelés mértéke a diabetestartam növekedésével párhuzamosan jelentősen csökkent. Vizsgálatok bizonyítják, hogy a még meglevő endogén inzulinrezerv kapacitás mellett jobb anyagcserestátusz érhető el. ${ }^{23}$ Szórványos közlések ugyan vannak, ${ }^{24}$ további vizsgála- tok szükségesek a klinikus számára egyik legfontosabb kérdés megválaszolásához, hogy a hosszú távú anyagcserekontroll minősége milyen hatással van az endogén inzulintermelés szintjének alakulására, azaz a tartósan jó anyagcserekontroll lassítja-e a maradék béta-sejtek pusztulását. 


\section{lrodalom}

1. Wilcox NS, Rui J, Hebrok M, Herold KC: Life and death of $\beta$ cells in Type 1 diabetes: A comprehensive review. I Autoimmun 2016; 71: 51-58. doi:10.1016/j.jaut.2016.02.001

2. Dabelea D, Mayer-Davis EJ, Andrews IS, Dolan LM, Pihoker C, Hamman RF, et al.: Clinical evolution of beta cell function in youth with diabetes: the SEARCH for Diabetes in Youth study. Diabetologia 2012; 55: 3359-3368. doi:10.1007/s00125-012-2719-6

3. Keymeulen B, Vandemeulebroucke E, Ziegler AG, Mathieu C, Kaufman L, Hale G, et al: Insulin needs after CD3-antibody therapy in new-onset type 1 diabetes. N Engl J Med 2005; 352: 2598-2608. doi:10.1056/NEJMoa043980

4. Cook JJ, Hudson I, Harrison LC, Dean B, Colman PG, Werther GA, et al.: Doubleblind controlled trial of azathioprine in children with newly diagnosed type I diabetes. Diabetes 1989; 38: 779-783. doi:10.2337/diabetes.38.6.779

5. Steele C, Hagopian WA, Gitelman S, Masharani U, Cavaghan M, Rother KI, et al: Insulin secretion in type 1 diabetes. Diabetes 2004; 53: 426-433. doi:10.2337/diabetes.53.2.426

6. Brown RJ, Sinaii N, Rother KI: Too much glucagon, too little insulin: time course of pancreatic islet dysfunction in new-onset type 1 diabetes. Diabetes Care 2008; 31: 1403-1404. doi:10.2337/dc08-0575

7. Herold KC, Hagopian W, Auger JA, Poumian-Ruiz E, Taylor L, Donaldson D, et al: Anti-CD3 monoclonal antibody in new-onset type 1 diabetes mellitus. N Engl J Med 2002; 346: 1692-1698. doi:10.1056/NEJMoa012864

8. Bonfanti R, Bazzigaluppi $E$, Calori G, Riva MC, Viscardi M, Bognetti E, et al.: Parameters associated with residual insulin secretion during the first year of disease in children and adolescents with type 1 diabetes mellitus. Diabet Med 1998; 15: 844-850. doi:10.1002/(SICI) 1096-9136(199810)15:10<844::AID-DIA679>3.0.C0;2-A

9. Karjalainen J, Salmela P, llonen J, Surcel HM, Knip M: A comparison of childhood and adult type I diabetes mellitus. N Engl J Med 1989; 320: 881-886. doi:10.1056/NEJM198904063201401

10. Sosenko JM, Palmer JP, Greenbaum CJ, Mahon J, Cowie C, Krischer JP, et al: Patterns of metabolic progression to type 1 diabetes in the Diabetes Prevention Trial-Type 1. Diabetes Care 2006; 29: 643-649. doi:10.2337/diacare.29.03.06.dc05-1006

11. Bizzarri C, Benevento D, Ciampalini P, Patera Ippolita P, Schiaffini R, Migliaccio A, et al: Clinical presentation and autoimmune characteristics of very young children at the onset of type 1 diabetes mellitus. J Pediatr Endocrinol Metab 2010; 23: 1151-1157. doi:10.1515/jpem.2010.180

12. Barker A, Lauria A, Schloot N, Hosszufalusi N, Ludvigsson J, Mathieu C, et al: Age-dependent decline of $\beta$-cell function in type 1 diabetes after diagnosis: a multi-centre longitudinal study. Diabetes Obes Metab 2014; 16: 262-267. doi: $10.1111 /$ dom. 12216

13. Mazarello Paes V, Charalampopoulos D, Edge J, Taylor-Robinson D, Stephenson $T$, Amin R: Predictors of glycemic control in the first year of diagnosis of childhood onset type 1 diabetes: A systematic review of quantitative evidence. Pediatr Diabetes 2017 May 10. doi:10.1111/pedi.12530. [Epub ahead of print]

14. Clements MA, Lind M, Raman S, Patton SR, Lipska KJ, Fridlington AG, et al.: Age at diagnosis predicts deterioration in glycaemic control among children and adolescents with type 1 diabetes. BMJ Open Diabetes Res Care 2014; 2 : e000 039. doi:10.1136/bmjdrc-2014-000039

15. Davis, AK, DuBose SN, Haller MJ, Miller KM, DiMeglio LA, Bethin KE, et al. for the T1D Exchange Clinic Network: Prevalence of Detectable C-Peptide According to Age at Diagnosis and Duration of Type 1 Diabetes. Diabetes Care 2015; 38: 476-481. doi:10.2337/dc14-1952
16. Buckingham B, Cheng P, Beck RW, Kollman C, Ruedy KJ, Weinzimer SA, et al.: Diabetes Research in Children Network (DirecNet) and Type 1 Diabetes TrialNet Study Groups. CGM-measured glucose values have a strong correlation with C-peptide, HbA ${ }_{1 c}$ and IDAAC, but do poorly in predicting C-peptide levels in the two years following onset of diabetes. Diabetologia 2015; 58: 1167-1174. doi:10.1007/s00125-015-3559-y

17. Pinhas-Hamiel O, Hamiel U, Boyko V, Graph-Barel C, Reichman B, Lerner-Geva $\mathrm{L}$ : Trajectories of $\mathrm{HbA}_{1 \mathrm{c}}$ levels in children and youth with type 1 diabetes. PLOS One 2014; 9: e109109. doi:10.1371/journal.pone.0109109

18. Chowdhury S.: Puberty and type 1 diabetes. Indian J Endocrinol Metab 2015; 19(Suppl 1): S51-S54. doi:10.4103/2230-8210.155402

19. The DCCT Research Group: Effect of intensive diabetes treatment on the development and progression of long-term complications in adolescents with insulin-dependent diabetes mellitus: Diabetes Control and Complications Trial. J Pediatr 1994; 125: 177-188. doi:10.1016/50022-3476(94)70190-3

20. Jones AG, Hattersley AT: The clinical utility of C-peptide measurement in the care of patients with diabetes. Diabet Med 2013; 30: 803-817. doi:10.1111/dme. 12159

21. Besser RE, Shields BM, Casas R, Hattersley AT, Ludvigsson J: Lessons from the mixed-meal tolerance test: use of 90-minute and fasting C-peptide in pediatric diabetes. Diabetes Care 2013; 36: 195-201. doi:10.2337/dc12-0836

22. Lachin JM, Orchard TJ, Nathan DM; DCCT/EDIC Research Group: Impact of C-Peptide Preservation on Metabolic and Clinical Outcomes in the Diabetes Control and Complications Trial. Diabetes 2014; 63: 739-748. doi: $10.2337 / \mathrm{db} 13-0881$

23. Nordwall M, Ludvigsson J: Clinical manifestations and beta cell function in Swedish diabetic children have remained unchanged during the last 25 years. Diabetes Metab Res Rev 2008; 24: 472-479. doi:10.1002/dmrr.871

24. Dantas JR, Almeida MH, Barone B, Serfaty F, Raggio LR, Kupfer R, et al.: Continuous C-peptide loss in patients with type 1 diabetes and multiethnic background. Diabetes Res Clin Pract 2013; 99: 33-36. doi:10.1016/j.diabres.2012.12.019

Közlésre érkezett: 2017. június 30.

Közlésre elfogadva: 2017. november 2.

\section{A szerzö levelezési címe:}

\section{Dr. Körner Anna}

Semmelweis Egyetem, I. Gyermekgyógyászati

Klinika

1083 Budapest, Bókay János u. 53-54.

E-mail: korner.anna@med.semmelweis-univ.hu 